\title{
Eksistensi Badan Layanan Umum Sebagai Penyelenggara Pelayanan Publik
}

\author{
Henny Juliani \\ Fakultas Hukum Universitas Diponegoro \\ Jl.Prof.Soedarto, SH Tembalang Semarang \\ juliani@gmail.com
}

\begin{abstract}
This study aims to determine the existence of public service agencies as public service providers in Indonesia. The research method used is legal research with statutory approach approach (analytical approach) which is analyzed with qualitative analysis. The results of the research show that the Public Service Agency (BLU) as the public service provider plays an important role in providing services to the public in the form of the provision of goods and / or services. Legally BLU is not a legal entity, but BLU operates as a working unit of state ministries / agencies / local governments for the purpose of providing public services whose management is based on the authority delegated by the respective parent agency. Therefore, the financial management is not separate from the state ministries / institutions / local government as the parent institution.
\end{abstract}

Keywords: Public Service Board, Public Service, State Organizer

\begin{abstract}
Abstrak
Penelitian ini bertujuan untuk mengetahui eksistensi badan layanan umum sebagai penyelenggara pelayanan publik di Indonesia. Metode penelitian yang digunakan adalah penelitian hukum dengan pendekatan statutory approach (pendekatan perundang-undangan) yang dianalisis dengan analisis kualitatif. Hasil penelitian menjukan bahwa Badan Layanan Umum (BLU) sebagai penyelenggara pelayanan publik berperan penting dalam memberikan layanan kepada masyarakat berupa penyediaan barang dan/atau jasa. Secara yuridis BLU bukan merupakan badan hukum, namun BLU beroperasi sebagai unit kerja kementerian negara/lembaga/pemerintah daerah untuk tujuan pemberian layanan umum yang pengelolaannya berdasarkan kewenangan yang didelegasikan oleh instansi induk yang bersangkutan. Oleh karena itu maka pengelolaan keuangannya tidak terpisah dari kementerian negara/lembaga/pemerintah daerah sebagai instansi induknya.
\end{abstract}

Kata Kunci: Badan Layanan Umum, Pelayanan Publik, Penyelenggara Negara

\section{A. Pendahuluan}

Tujuan nasional sebagaimana ditegaskan dalam Alinea IV Pembukaan Undang-undang Dasar Negara Republik Indonesia Tahun 1945 adalah untuk mewujudkan masyarakat Indonesia yang sejahtera, berkedaulatan rakyat, dan demokratis dengan mengutamakan kesatuan dan persatuan bangsa, berdasarkan Pancasila dan Undang-undang Dasar Negara Republik Indonesia Tahun 1945. Tujuan nasional tersebut dilaksanakan melalui penyelenggaraan negara oleh pemerintah sebagai 
pengemban kedaulatan rakyat. Hal tersebut diwujudkan dalam bentuk pelaksanaan pemerintahan umum dan kegiatan pembangunan pada segala aspek kehidupan bangsa.

Peranan pemerintah yang sedemikian besar tersebut merupakan manifestasi dari dianutnya ajaran negara hukum modern yang dikenal dengan konsep negara kesejahteraan (welfare state). Dalam konsep negara kesejahteraan (welfare state), pemerintah ditempatkan sebagai pihak yang bertanggungjawab atas kesejahteraan rakyatnya. Oleh karena itu maka pemerintah terlibat aktif dalam segala aspek kehidupan rakyatnya dengan mencampuri kehidupan ekonomi maupun sosial di samping tentunya tetap menjaga ketertiban dan keamanan.

Undang-undang Dasar Negara Republik Indonesia Tahun 1945 menegaskan dalam Pasal 4 ayat (1) bahwa Presiden Republik Indonesia memegang kekuasaan pemerintahan menurut Undangundang Dasar. Berdasarkan ketentuan tersebut maka penyelenggaraan tugas-tugas pemerintahan yang dilaksanakan oleh Presiden dalam negara kesatuan Republik Indonesia merupakan bentuk sentralisasi yang berarti seluruh bidang-bidang pemerintahan diselenggarakan oleh pemerintah pusat. Di sisi lain dikenal pula penyelenggaraan tugas-tugas pemerintahan yang tidak hanya dijalankan oleh pemerintah pusat tetapi diselenggarakan oleh pemerintahan daerah dalam bentuk desentralisasi.

Penyelenggaraan pemerintahan daerah dalam bentuk desentralisasi berdasarkan Undang-undang Dasar Negara Republik Indonesia Tahun 1945 memberi wewenang kepada pemerintahan daerah untuk mengatur dan mengurus sendiri urusan pemerintahan menurut asas otonomi dan tugas pembantuan. Desentralisasi dimaksudkan untuk mempercepat terwujudnya kesejahteraan masyarakat melalui peningkatan pelayanan, pemberdayaan dan peran serta masyarakat serta peningkatan daya saing daerah dengan memerhatikan prinsip demokrasi, pemerataan, keadilan, keistimewaan dan kekhususan suatu daerah dalam sistem Negara Kesatuan Republik Indonesia, oleh karena itu menjadi tanggung jawab daerah pula dalam mewujudkan tujuan nasional.

Untuk mewujudkan tujuan nasional maka pemerintah pusat dan pemerintah daerah harus bersinergi dalam memajukan kesejahteraan umum dan mencerdaskan kehidupan bangsa sebagaimana amanat Undang-undang Dasar Negara Republik Indonesia Tahun 1945. Dalam Penjelasan Umum Undang-undang Nomor 25 Tahun 2009 tentang Pelayanan Publik, amanat tersebut mengandung makna negara berkewajiban memenuhi kebutuhan setiap warga negara melalui suatu sistem pemerintahan yang mendukung terciptanya penyelenggaraan pelayanan publik yang prima dalam rangka memenuhi kebutuhan dasar dan hak sipil setiap warga negara atas barang publik, jasa publik, dan pelayanan administrasi.

Menurut H.A. Muin Fahmal, pejabat administrasi (bestuur) selaku pelaksana kebijakan politik negara mempunyai wewenang sebagaimana diperintahkan undang-undang. Berfungsi memimpin masyarakat, mengendalikan pemerintahan, memberi petunjuk, menghimpun aspirasi, menggerakkan 
potensi, memberi arah, mengkoordinasikan kegiatan, membuka kesempatan, memberi kemudahan, mengawasi, menilai, mendukung, membina, melayani, mendorong, dan melindungi masyarakat. Hakikat fungsi pemerintah (pejabat administrasi ) adalah sebagai pelayan masyarakat.

Pelayanan publik menurut Pasal 1 angka 1 Undang-undang Nomor 25 Tahun 2009 tentang Pelayanan Publik adalah

"kegiatan atau rangkaian kegiatan dalam rangka pemenuhan pelayanan sesuai dengan peraturan perundang-undangan bagi setiap warga negara dan penduduk atas barang, jasa, dan/atau pelayanan administratif yang disediakan oleh penyelenggara pelayanan publik."

Selanjutnya menurut Pasal 1 angka 2:

"Penyelenggara pelayanan publik yang selanjutnya disebut sebagai penyelenggara adalah setiap institusi penyelenggara negara, korporasi, lembaga independen yang dibentuk berdasarkan Undang-undang untuk kegiatan pelayanan publik, dan badan hukum lain yang dibentuk sematamata untuk kegiatan pelayanan publik."

Menurut Mediya Lukman, institusi penyelenggara layanan publik dapat digolongkan ke dalam 3 (tiga) bentuk yakni institusi birokrasi biasa dengan derajat otonomi dan kemandirian yang terbatas atau tidak ada sama sekali, BLU/D sebagai institusi yang semi otonom, dan BUMN/D sebagai institusi publik/negara yang benar-benar otonom dalam mengelola setiap sumber daya dan pembuatan keputusan. Dalam perkembangan selanjutnya setelah keluarnya Undang-undang Nomor 24 Tahun 2011 tentang Badan Penyelenggara Jaminan Sosial, dan Undang-undang Nomor 12 Tahun 2012 tentang Pendidikan Tinggi maka ditambahkan 1 (satu) bentuk lagi institusi penyelenggara layanan publik yang memiliki otonomi dan diskresi jauh lebih besar daripada institusi /organisasi publik yang berbentuk BLU yaitu BPJS dan PTN badan hukum.

Dari beberapa institusi penyelenggara layanan publik tersebut, yang cukup menarik untuk diamati dan dikaji lebih mendalam adalah dalam bentuk Badan Layanan Umum (BLU). Hal itu berawal dari adanya suatu pemikiran bahwa setelah berlakunya Undang-undang Nomor 19 Tahun 2003 tentang Badan Usaha Milik Negara hanya diatur adanya 2 (dua) bentuk BUMN saja yaitu Perusahaan Umum (Perum) dan Perusahaan Perseroan (Persero), sedangkan bentuk Perusahaan Jawatan (Perjan) tidak dikenal lagi karena Pasal 93 ayat (1) Undang-undang Nomor 19 Tahun 2003 tentang BUMN menyatakan bahwa dalam waktu 2 (dua) tahun terhitung sejak Undang-undang ini berlaku semua BUMN yang berbentuk Perusahaan Jawatan (Perjan) harus telah diubah bentuknya menjadi Perusahaan Umum (Perum) ataupun Perusahaan Perseroan (Persero). Selanjutnya keberadaan Perusahaan Jawatan (Perjan) yang mempunyai tujuan untuk menyelenggarakan pelayanan umum tanpa bermaksud mencari keuntungan digantikan oleh Badan Layanan Umum (BLU), kalau dapat dikatakan demikian.

Konsep penyelenggaraan layanan publik dalam bentuk Badan Layanan Umum (BLU) didasarkan pada Undang-undang Nomor 1 Tahun 2004 tentang Perbendaharaan Negara, Peraturan 
Adminitrative Law \& Governance Journal Vol. 1 Edisi Khusus 12018 ISSN 2621 - 2781 Online

Pemerintah Nomor 23 Tahun 2005 tentang Pengelolaan Keuangan Badan Layanan Umum, walaupun juga didukung oleh berbagai peraturan perundang-undangan lainnya yaitu Undang-undang Nomor 17 Tahun 2003 tentang Keuangan Negara; Undang-undang Nomor 15 Tahun 2004 tentang Pemeriksaan Pengelolaan dan Tanggung Jawab Keuangan Negara; Undang-undang Nomor 25 Tahun 2009 tentang Pelayanan Publik; maupun Peraturan Pemerintah Nomor 58 Tahun 2005 tentang Pengelolaan Keuangan Daerah.

Badan Layanan Umum menurut Pasal 1 angka 23 Undang-undang Nomor 1 Tahun 2004 tentang Perbendaharaan Negara adalah:

Instansi di lingkungan Pemerintah yang dibentuk untuk memberikan pelayanan kepada masyarakat berupa penyediaan barang dan/atau jasa yang dijual tanpa mengutamakan mencari keuntungan dan dalam melakukan kegiatannya didasarkan pada prinsip efisiensi dan produktivitas

Selanjutnya dalam Penjelasan Umum Undang-undang tersebut ditegaskan bahwa pelayanan kepada masyarakat tersebut diperlukan dalam rangka memajukan kesejahteraan umum dan mencerdaskan kehidupan bangsa. Selain itu juga dinyatakan bahwa kekayaan Badan Layanan Umum merupakan kekayaan negara yang tidak dipisahkan serta dikelola dan dimanfaatkan sepenuhnya untuk menyelenggarakan kegiatan Badan Layanan Umum yang bersangkutan.

Berkenaan dengan itu, rencana kerja dan anggaran serta laporan keuangan dan kinerja Badan Layanan Umum disusun dan disajikan sebagai bagian yang tidak terpisahkan dari rencana kerja dan anggaran serta laporan keuangan kementerian negara/lembaga/pemerintah daerah. Adapun pembinaan keuangan Badan Layanan Umum dilakukan oleh Menteri Keuangan, sedangkan pembinaan teknis dilakukan oleh menteri yang bertanggung jawab atas bidang pemerintahan yang bersangkutan.

\section{Permasalahan}

Penelitian ini akan mengajukan permasalahan sebagai berikut, bagaimanakah eksistensi kajian yuridis terhadap peranan Badan Layanan Umum (BLU) sebagai penyelenggara pelayanan public di Indonesia.

\section{Metode Penelitian}

Masalah pokok dalam penelitian ini adalah kajian yuridis terhadap Badan Layanan Umum (BLU) sebagai model penyelenggaraan pelayanan publik. Masalah tersebut dikaji dari sudut pandang hukum dengan menggunakan pendekatan yuridis normatif, karena masalah yang akan diteliti tersebut berhubungan erat dengan law in book. Penelitian hukum normatif merupakan penelitian kepustakaan, yaitu penelitian yang dilakukan dari data sekunder.

Untuk mendekati permasalahan dipergunakan spesifikasi penelitian deskriptif analitis, yaitu menggambarkan peraturan perundang-undangan yang berlaku dikaitkan dengan teori-teori hukum 
yang mendukung penyelesaian permasalahan untuk selanjutnya dilakukan analisa secara kritis terhadap permasalahan tersebut.

\section{B. Pembahasan}

\section{Eksistensi Badan Layanan Umum (BLU) sebagai Penyelenggara Pelayanan Publik}

Badan Layanan Umum (BLU) pada awalnya adalah merupakan satuan kerja (satker)/instansi biasa di kementerian negara/lembaga yang sebenarnya tunduk kepada ketentuan/asas universalitas dalam hal pengelolaan keuangan negara. Satker/instansi birokrasi biasa ini sebagian besar sebelumnya merupakan satker/instansi pengelola Penerimaan Negara Bukan Pajak (PNBP). Satkersatker ini pada umumnya menerima dana PNBP dari masyarakat karena satker-satker tersebut menyediakan pelayanan kepada masyarakat. Oleh karena sistem dan pola pengelolaan keuangan melalui mekanisme PNBP tidak memadai lagi (pasca reformasi politik dan keuangan) dalam hal peningkatan kualitas pelayanan kepada masyarakat, terutama bagi satker PNBP yang menyediakan pelayanan jasa pendidikan dan kesehatan (perguruan tinggi dan rumah sakit).

Dibentuklah Badan Layanan Umum (BLU) berdasarkan Undang-undang Nomor 1 Tahun 2004 tentang Perbendaharaan Negara Pasal 1 angka 23 yang menyatakan bahwa: “ BLU adalah instansi di lingkungan pemerintah yang dibentuk untuk memberikan pelayanan kepada masyarakat berupa penyediaan barang dan/atau jasa yang dijual tanpa mengutamakan mencari keuntungan dan dalam melakukan kegiatannya didasarkan pada prinsip efisiensi dan produktivitas." Selanjutnya menurut Pasal 68 ayat (2) Undang-undang Nomor 1 Tahun 2004 tentang Perbendaharaan Negara, kekayaan BLU merupakan kekayaan negara/daerah yang tidak dipisahkan serta dikelola dan dimanfaatkan sepenuhnya untuk menyelenggarakan kegiatan BLU yang bersangkutan. Berdasarkan ketentuan tersebut, maka tata kelola keuangan BLU juga mengacu pada ketentuan pengelolaan keuangan negara.

Untuk itu maka dikeluarkan Peraturan Pemerintah Nomor 23 Tahun 2005 tentang Pengelolaan Keuangan BLU, walaupun dalam manajemen BLU juga didukung oleh berbagai peraturan perundang-undangan lainnya seperti Undang-undang Nomor 17 Tahun 2003 tentang Keuangan Negara; Undang-undang Nomor 15 Tahun 2004 tentang Pemeriksaan Pengelolaan dan Tanggung Jawab Keuangan Negara; Undang-undang Nomor 25 Tahun 2009 tentang Pelayanan Publik; maupun Peraturan Pemerintah Nomor 58 Tahun 2005 tentang Pengelolaan Keuangan Daerah.

\section{Status Hukum Badan Layanan Umum (BLU)}

Dilihat dari rumusan BLU menurut Pasal 1 angka 23 Undang-undang Nomor 1 Tahun 2004 tentang Perbendaharaan Negara yang merumuskan bahwa: "BLU adalah instansi di lingkungan 
Adminitrative Law \& Governance Journal Vol. 1 Edisi Khusus 12018 ISSN 2621 - 2781 Online

pemerintah yang dibentuk untuk memberikan pelayanan kepada masyarakat berupa penyediaan barang dan/atau jasa yang dijual tanpa mengutamakan mencari keuntungan dan dalam melakukan kegiatannya didasarkan pada prinsip efisiensi dan produktivitas." Dari rumusan tersebut jelas bahwa BLU adalah instansi dalam lingkungan pemerintah yang dibentuk untuk memberikan layanan kepada masyarakat dengan imbalan uang, namun dalam melaksanakan fungsinya BLU tidak bertujuan mengutamakan mencari keuntungan. Oleh karena itu jelaslah terlihat bahwa BLU diperbolehkan mencari keuntungan, meskipun bukan merupakan tujuan utamanya.

Ada perbedaan antara instansi birokrasi/pemerintah biasa dengan BLU yakni hanya sebatas pada pengecualian terhadap tata cara pengelolaan keuangannya. Instansi pemerintah tunduk pada asas "universalitas" atau "universaliteit beginsel", sedangkan terhadap pengelolaan keuangan BLU tidak berlaku asas tersebut. Hal tersebut dapat dilihat dalam ketentuan Pasal 1 Angka 2. Peraturan Pemerintah Nomor 23 Tahun 2005 tentang Pengelolaan Keuangan BLU sebagai Pola Pengelolaan Keuangan Badan Layanan Umum (PPK-BLU), sebagai berikut:

"Pola Pengelolaan Keuangan Badan Layanan Umum yang selanjutnya disebut PPK-BLU, adalah pola pengelolaan keuangan yang memberikan fleksibilitas berupa keleluasaan untuk menerapkan praktek-praktek bisnis yarg sehat untuk meningkatkan pelayanan kepada masyarakat dalam rangka memajukan kesejahteraan umum dan mencerdaskan kehidupan bangsa, sebagaimana diatur dalam Peraturan Pemerintah ini. sebagai pengecualian dan ketentuan pengelolaan keuangan negara pada umumnya."

Secara status hukum BLU bukan merupakan badan hukum atau subjek hukum, sehingga timbul pertanyaan bagaimana BLU dapat melakukan perbuatan hukum dengan pihak ketiga kalau BLU bukan berbadan hukum atau bukan sebagai subjek hukum?. Hal ini sebenarnya dapat terjawab dengan ketentuan yang diatur dalam Pasal 3 ayat (1) Peraturan Pemerintah Nomor 23 Tahun 2005 yang berbunyi sebagai berikut: "BLU beroperasi sebagai unit kerja kementerian negara/lembaga/pemerintah daerah untuk tujuan pemberian layanan umum yang pengelolaannya berdasarkan kewenangan yang didelegasikan oleh instansi induk yang bersangkutan.”

Berdasarkan ketentuan tersebut maka dapat dikatakan bahwa BLU dapat melakukan perbuatan hukum dengan pihak ketiga karena telah menerima delegasi dari instansi induknya. Dengan demikian kewenangannya melakukan perbuatah hukum, misalnya perjanjian yang dibuat antara BLU dengan pihak ketiga adalah sah karena kementerian/lembaga/pemerintah daerah selaku pemerintah bertindak untuk dan atas nama badan hukum negara atau badan hukum daerah telah mendelegasikannya kepada BLU/D. 
Demikian pula status hukum BLU/D telah diatur dalam Pasal 3 ayat (2) Peraturan Pemerintah Nomor 23 Tahun 2005 tentang Pengelolaan Keuangan BLU, yang berbunyi sebagai berikut:

"BLU merupakan bagian perangkat pencapaian tujuan kementerian negara/lembaga/pemerintah daerah dan karenanya status hukum BLU tidak terpisah dari kementerian negara/lembaga/pemerintah daerah sebagai instansi induk."

Dari rumusan tersebut di atas jelas bahwa BLU/D bukan merupakan subjek hukum yang mandiri karena status hukum BLU tidak terpisah dari kementerian negara/lembaga/pemerintah daerah sebagai instansi induk. Dengan kata lain BLU merupakan institusi penyelenggara layanan publik yang bersifat semi otonom karena masih terikat dengan organisasi kementerian induk masing-masing.

\section{Penetapan dan Pencabutan BLU/D}

Dalam Peraturan Pemerintah Nomor 23 Tahun 2005 tentang Pengelolaan Keuangan BLU, untuk pendirian atau pembubaran suatu BLU/D digunakan istilah penetapan dan pencabutan. Istilah ini digunakan karena BLU bukan badan hukum tetapi instansi dalam lingkungan pemerintah sehingga tidak ada suatu organisasi yang dibubarkan. Menurut Arifin P. Soeria Atmadja, penggunaan istilah penetapan dan pencabutan adalah tepat karena yang ditetapkan atau dicabut adalah sistemnya yang disebut Pola Pengelolaan Keuangan BLU (PPK-BLU), sehingga apabila PPK-BLU dari surat BLU atau BLUD dicabut, ia akan kembali menjadi instansi dalam lingkungan pemerintah yang bersangkutan dan sistem pengelolaan keuangan dan lainnya berjalan seperti halnya instansi pemerintah biasa yang tunduk pada tata cara pengelolaan keuangan APBN atau APBD.

Selanjutnya Pasal 4 ayat (1) Peraturan Pemerintah Nomor 23 Tahun 2004 tentang Pengelolaan Keuangan Badan Layanan Umum, telah menentukan syarat-syarat yang harus dipenuhi terlebih dahulu agar suatu instansi berhak mengubah statusnya menjadi BLU atau BLUD. Adapun syarat-syarat yang harus dipenuhi agar instansi di lingkungan pemerintah pusat maupun daerah memperoleh ijin mengelola keuangan dengan Pola Pengelolaan Keuangan BLU (PPKBLU) atau PPK-BLUD terlebih dahulu harus memenuhi syarat: (a) substantif, (b) teknis, dan (c) syarat administratif sebagai berikut:

"Suatu satuan kerja instansi pemerintah dapat diizinkan mengelola keuangan dengan PPKBLU apabila memenuhi persyaratan substantif, teknis, dan administratif."

Suatu instansi dalam lingkungan pemerintah dapat berubah statusnya menjadi BLU/D setelah diusulkan kepada Menteri Keuangan untuk status BLU dan kepada Gubernur, Bupati atau 
Walikota untuk status BLUD. Hal tersebut diatur dalam ketentuan Pasal 5 ayat (4) dan (5) Peraturan Pemerintah Nomor 23 Tahun 2004 tentang Pengelolaan Keuangan BLU.

Sesuai dengan tujuan diterapkannya PPK-BLU oleh instansi pemerintah, dalam menetapkan tarif harus didasarkan pada standar pelayanan minimum yang ditetapkan oleh menteri, gubernur, bupati atau walikota sesuai dengan kewenangannya. Hal tersebut diatur dalam ketentuan Pasal 8 ayat (1) beserta penjelasannya dari Peraturan Pemerintah Nomor 23 Tahun 2004 tentang Pengelolaan Keuangan BLU.

Termasuk dalam kualitas layanan meliputi teknis layanan, proses layanan, tata cara dan waktu tunggu untuk mendapatkan layanan. Selanjutnya karena BLU/D dapat memungut biaya dari masyarakat sebagai imbalan atas barang/jasa layanan yang diberikan, diperlukan standar tarif yang ditetapkan berdasarkan perkiraan unit cost layanan atau hasil per investasi dana. Tarif layanan tersebut diusulkan BLU/BLUD kepada menteri, pimpinan lembaga atau kepala SKPD sesuai dengan kewenangannya. Selanjutnya penetapan tarif yang diusulkan tersebut dilakukan oleh Menteri Keuangan, gubernur, bupati atau walikota. Termasuk ke dalam pengertian tarif adalah imbalan hasil (return) yang wajar dari investasi dana, yang dapat bertujuan untuk menutupi seluruh atau sebagian dari biaya per unit layanan. Dalam menentukan tarif layanan perlu pula dipertimbangkan hal-hal yang berkaitan dengan:

a) Kontinuitas dan pengembangan layanan;

b) Daya beli masyarakat;

c) Asas keadilan dan kepatutan;

d) Kualitas layanan, dan;

e) Kompetisi yang sehat

\section{Pola Pengelolaan Keuangan (PPK) BLU/BLUD}

\section{Rencana Bisnis dan Anggaran BLU/BLUD}

Sebagaimana telah dikemukakan pada bagian terdahulu, Pola Pengelolaan Keuangan BLU/BLUD adalah dikecualikannya asas "universalitas" yang berlaku bagi APBN dan APBD, namun terhadap BLU/BLUD diterapkan manajemen perusahaan atau bisnis sehingga setiap BLU/BLUD pada awal tahun harus menyiapkan Rencana Bisnis dan Anggaran (RBA) yang mengacu pada Rencana Strategis Kementerian Negara/Lembaga (Renstra-KL) atau Rencana Pembangunan Jangka Menengah Daerah (RPJMD). BLU/BLUD menggunakan APBN/APBD yang telah disetujui oleh DPR/DPRD dan disahkan oleh Pemerintah/Pemerintah Daerah. BLU/BLUD menggunakan APBN/APBD yang telah ditetapkan sebagai dasar penyesuaian terhadap RBA menjadi RBA definitif. Pengecualian asas "universalitas" ini secara tegas dirumuskan dalam Pasal 69 ayat (6) Undang-undang Nomor 1 Tahun 2004 tentang Perbendaharaan 
Negara, maupun dalam Pasal 14 ayat (5) Peraturan Pemerintah Nomor 23 Tahun 2005 tentang Pengelolaan Keuangan BLU.

Selanjutnya RBA-BLU atau RBA-BLUD sedikitnya mencakup seluruh pendapatan dan belanja, proyeksi arus kas, serta jumlah dan kualitas jasa dan/atau barang yang akan dihasilkan oleh BLU atau BLUD, dimana Menteri Keuangan atau Pejabat Pengelola Keuangan Daerah (PPKD) mengesahkan paling lambat tanggal 31 Desember menjelang akhir tahun anggaran. Dokumen pelaksanaan anggaran yang sudah disahkan oleh Menteri Keuangan/PPKD sesuai dengan kewenangannya menjadi dasar bagi penarikan dana yang bersumber APBN/APBD oleh BLU/BLUD.Dalam hal BLU/BLUD kekurangan anggaran, BLU/BLUD dapat mengajukan usulan tambahan dari APBN/APBD. Hal ini menunjukkan bahwa status BLU/BLUD masih tetap berada dalam lingkungan pemerintah, apalagi belanja BLU/BLUD dilaporkan sebagai belanja barang dan jasa kementerian negara/lembaga/SKPD/Pemerintah Daerah.

\section{Pendapatan dan Belanja BLU/BLUD}

Penerimaan anggaran yang bersumber dari APBN/APBD diberlakukan sebagai pendapatan BLU/BLUD. Penerimaan yang dimaksud adalah penerimaan yang berasal dari otorisasi kredit anggaran kementerian negara/lembaga/pemerintah daerah, bukan dari kegiatan pembiayaanAPBN/APBD. Demikian pula pendapatan yang bersumber dari hasil kerjasama BLU/BLUD dengan pihak lain dan/atau hasil usaha lainnya merupakan pendapatan bagi BLU/BLUD yang dapat dikelola langsung untukmembiayai belanja BLU/BLUD sesuai dengan Rencana Bisnis dan Anggaran (RBA). Sementara itu pendapatan yang diperoleh dari jasa kepada masyarakat dan hibah tidak terkait dengan layanan yang diperoleh dari masyarakat atau dari badan lain, merupakan pendapatan operasional. Pendapatan operasional tersebut dilaporkan sebagai Penerimaan Negara Bukan Pajak (PNBP) kementerian/lembaga atau penerimaan bukan pajak dari pemerintah daerah.

Belanja BLU/BLUD terdiri dari unsur biaya yang sesuai dengan struktur biaya yang tertuang dalam RBA definitif, yang pengelolaannya bersifat fleksibel berdasarkan kesetaraan antara volume kegiatan pelayanan dengan jumlah pengeluaran sesuai dengan praktek bisnis yang sehat. Pengertian fleksibilitas pengelolaan belanja berlaku dalam ambang batas sesuai dengan yang ditetapkan dalam RBA, sehingga kalau belanja akan melampaui ambang batas RBA harus mendapat persetujuan terlebih dahulu dari Menteri Keuangan untuk BLU dan gubernur, bupati/walikota untuk BLUD atas usulan menteri/pimpinan lembaga/kepala SKPD sesuai dengan kewenangannya. Selanjutnya dalam hal terjadi kekurangan anggaran, BLU dapat mengajukan usulan tambahan anggaran dari APBN/APBD kepada Menteri Keuangan/PPKD melalui menteri/pimpinan lembaga/kepala SKPD sesuai dengan kewenangannya. Belanja BLU/BLUD 
Adminitrative Law \& Governance Journal Vol. 1 Edisi Khusus 12018 ISSN 2621 - 2781 Online

dilaporkan sebagai belanja barang dan jasa kementerian negara/lembaga/SKPD/ Pemerintah Daerah. Ketentuan tersebut dapat dilihat dalam Pasal 14 dan 15 Peraturan Pemerintah Nomor 23 Tahun 2005 tentang Pengelolaan Keuangan BLU.

\section{Investasi BLU/BLUD}

Berdasarkan Pasal 19 ayat (1) Peraturan Pemerintah Nomor 23 Tahun 2005 tentang Pengelolaan Keuangan BLU, BLU/BLUD tidak dapat melakukan investasi jangka panjang kecuali atas ijin Menteri Keuangan, gubernur, bupati/walikota. Demikian investasi jangka pendek hanya diperbolehkan untuk investasi dengan risiko rendah, tidak untuk investasi jangka menengah, atau jangka panjang yang mempunyai risiko tinggi, termasuk di dalamnya investasi portofolio. Keuntungan yang diperoleh dari investasi jangka panjang merupakan pendapatan BLU/BLUD dan bukan merupakan Penerimaan Negara Bukan Pajak (PNBP) atau Penerimaan Pemerintah Daerah Bukan Pajak (PDBP).

\section{Pengelolaan Barang BLU/BLUD}

Siklus pengadaan atau siklus logistik dalam bentuk barang dan/atau jasa pada umumnya dimulai dari perencanaan/ penganggaran, pengadaan, pendistribusian, penyimpanan, penggunaan, pemeliharaan dan penghapusan yang disertai pertanggungjawaban. Pengadaan barang dan jasa BLU/BLUD dalam menjalankan siklus tersebut dilakukan berdasarkan prinsip efisiensi dan ekonomis sesuai dengan praktek bisnis yang sehat. Perencanaan pengadaan barang harus didasarkan pada RBA BLU/BLUD yang tercermin dalam APBN maupun APBD karena landasan RBA BLU dilakukan berdasarkan APBN kementerian teknis terkait yang merupakan sumber anggaran BLU, sedangkan BLUD berdasarkan pada APBD. Hal ini dilakukan terutama untuk belanja modal, sehingga keuangan BLU adalah keuangan negara dan keuangan BLUD adalah keuangan daerah.

Menurut Pasal 21 ayat (1) Peraturan Pemerintah Nomor 23 Tahun 2005, barang inventaris milik BLU/BLUD dapat dialihkan kepada pihak lain dan/atau dihapuskan berdasarkan pertimbangan ekonomis. Pengalihan inventaris BLU/BLUD kepada pihak lain dilakukan dengan cara dijual, dipertukarkan, atau dihibahkan, dan penerimaan hasil penjualan barang inventaris merupakan pendapatan BLU/BLUD. Pengalihan dan/atau penghapusan barang inventaris dilaporkan kepada menteri/pimpinan dan kepala SKPD bersangkutan.

BLU atau BLUD tidak dapat menghapuskan aset tetap, kecuali atas persetujuan pejabat yang berwenang. Aset tetap yang dimaksud adalah aset berwujud yang mempunyai masa manfaat lebih dari dua belas bulan untuk digunakan dalam kegiatan BLU/BLUD atau dimanfaatkan oleh masyarakat umum, sesuai dengan standar akuntansi yang berlaku. Dalam Peraturan Pemerintah Nomor 23 Tahun 2005, tidak dijelaskan siapa pejabat yang berwenang memberikan persetujuan 
pemindahtanganan aset BLU/BLUD. Namun, karena BLU dan BLUD bukan merupakan badan hukum, tetapi merupakan instansi dalam lingkungan pemerintah, ketentuan yang tercantum dalam Pasal 46 Undang-undang Nomor 1 Tahun 2004, tentang Perbendaharaan Negara merupakan petunjuk siapa yang berwenang memberikan persetujuan tersebut. Hal ini dapat pula disimpulkan dari Pasal 23 ayat (1) Peraturan Pemerintah Nomor 23 Tahun 2005, dimana ditetapkan aset berupa tanah dan bangunan BLU disertifikatkan atas nama Pemerintah Republik Indonesia, sedangkan aset berupa tanah dan bangunan BLUD disertifikatkan atas nama Pemerintah Daerah bersangkutan. Selanjutnya, tanah dan bangunan yang tidak digunakan BLU/BLUD untuk penyelenggaraan tugas pokok dan fungsinya, dapat dialihgunakan oleh menteri/pimpinan lembaga/kepala SKPD terkait dengan persetujuan Menteri Keuangan untuk BLU dan oleh gubernur, bupati atau walikota sesuai dengan kewenangannya.

Penerimaan hasil sebagai akibat penjualan aset tetap merupakan pendapatan BLU atau BLUD. Terhadap ketentuan seharusnya dibedakan aset tetap yang dibeli atas beban APBN atau APBD. Jika aset tetap atas beban APBN, seharusnya merupakan penerimaan PNBP dari kementerian/lembaga yang bersangkutan. Demikian pula bila aset tetap yang pengadaannya berasal dari APBD, seharusnya merupakan PDBP dari provinsi/ kabupaten atau kota terkait.

\section{Penyelesaian Kerugian BLU/BLUD}

Ketentuan mengenai kerugian negara/daerah pada BLU/BLUD yang disebabkan tindakan melanggar hukum atau kelalaian seseorang diselesaikan sesuai dengan ketentuan peraturan perundang-undangan mengenai penyelesaian kerugian negara atau daerah. Adapun peraturan perundang-undangan mengenai penyelesaian kerugian tersebut termuat dalam Undang-undang Nomor 1 Tabun 2004 tentang Perbendaharaan Negara jo. Undang Undang Nomor 15 Tahun 2004 tentang Pemeriksaan Pengelolaan dan Tanggung Jawab Keuangan Negara. Dalam ketentuan peraturan perundang-perundangan tersebut dibedakan antara pegawai biasa dan bendaharawan. Keputusan ganti rugi bagi "pegawai biasa" ditetapkan oleh menteri/pimpinan lembaga/ kepala SKPD yang bersangkutan, sedangkan kerugian yang disebabkan oleh kelalaian atau kesengajaan "bendahara" ditetapkan oleh Badan Pemeriksa Keuangan (BPK).

Kewenangan BPK menetapkan keputusan ganti rugi kepada bendaharawan ini jelas merupakan saduran dari ketentuan Pasal 77 Indische Comptabiliteitswet (ICW Stbl.1924 Nr.1925), menurut P. Alons sebagaimana dikutip oleh Arifin P. Soeria Atmadja yang pada waktu itu dipandang tepat karena Algemene Rekenkamer mempunyai kewenangan peradilan perbendaharaan (Comptabelrechts spraak), yang keputusannya mempunyai nilai hukum yang sama (in kracht) dengan putusan Pengadilan Negeri yang mempunyai kekuatan hukum pasti dalam perkara perdata 
Adminitrative Law \& Governance Journal Vol. 1 Edisi Khusus 12018 ISSN 2621 - 2781 Online

sebagaimana ditetapkan dalam Pasal 58 ayat (2) Indische Comptabiliteitswet (ICW Stbl 1925 Nr 448).

\section{Akuntansi, Pelaporan, dan pertanggungjawaban Keuangan}

Sistem manajemen keuangan BLU/BLUD dilakukan dengan kebutuhan dan praktik bisnis yang sehat, sedangkan setiap transaksi BLU/BLUD harus diakuntansikan dan dokumen pendukungnya dikelola secara tertib. Hal ini dilakukan agar dalam setiap rapat BLU dan BLUD selalu dilakukan secara tertib dan dokumen berlaku sebagai tanda atau bukti alasan suatu kebijakan yang diambil oleh pimpinan BLU atau BLUD, dimana pejabat pengelola dari BLU atau BLUD terdiri dari unsur: (a) pimpinan; (b) pejabat keuangan; dan (b) pejabat teknis. pimpinan sebagaimana dimaksud tersebut angka a di atas merupakan pejabat yang berfungsi sebagai penanggung jawab umum operasional dan keuangan BLU/BLUD dengan kewajiban antara lain:
a) menyiapkan rencana strategic bisnis BLU/IBLUD;
b) menyiapkan RBA tahunan;
c) mengusulkan calon pejabat keuangan dan pejabat teknis sesuai dengan ketentuan yang berlaku; dan
d) menyampaikan pertanggungjawaban kinerja operasional dan keuangan BLU/BLUD.

Selanjutnya, pejabat keuangan berfungsi sebagai penanggung jawab keuangan yang mempunyai kewajiban, di antaranya:
a) mengkoordinasikan penyusunan RBA;
b) menyiapkan dokumen pelaksanaan anggaran BLU/BLUD;
c) melakukan pengelolaan dan belanja;
d) menyelenggarakan pengelolaan kas;
e) melakukan pengelolaan utang-piutang;
f) menyusun kebijakan pengelolaan barang, aset tetap, dan investasi BLU/BLUD;
g) menyelenggarakan sistem informasi manajemen keuangan; dan
h) menyelenggarakan akuntansi dan penyusunan laporan keuangan.

Dari sejumlah kewajiban tersebut, pejabat keuangan tetap melaksanakannya dengan sistem keuangan APBN/APBD mengingat keuangan BLU/BLUD adalah keuangan negara yang tidak dipisahkan dan masih dalam koridor pengelolaan keuangan negara atau keuangan daerah, seperti menggunakan surat permintaan pembayaran (SPM) dan sebagainya, meskipun dengan menggunakan Pola pengelolaan Keuangan Badan Layanan Umum (PPK BLU). Selanjutnya, pejabat teknis BLU/BLUD berfungsi sebagai penanggung jawab teknis di bidang masing-masing yang berkewajiban antara lain: 
a) menyusun perencanaan kegiatan teknis di bidangnya;

b) melaksanakan kegiatan teknis sesuai menurut RBA;

c) mempertanggungjawabkan kinerja operasional di bidangnya.

Adapun pegawai sebagai pelaksana harian BLU/BLUD adalah pegawai yang dilakukan dengan out sourcing, contracting out atau pegawai BLU/BLUD murni yang diangkat, digaji, dan diberhentikan oleh pimpinan BLU/BLUD. Kemungkinan memperbantukan Pegawai Negeri Sipil (PNS) dimungkinkan, namun sistem penggajian tetap diberlakukan berdasarkan Undang-undang Nomor 43 Tahun 1999 tentang Perubahan Atas Undang-undang Nomor 8 Tahun 1974 tentang Pokok-pokok Kepegawaian, sejak tahun 2014 berdasarkan pada Undang-undang Nomor 5 Tahun 2014 tentang Aparatur Sipil Negara. Remunerasi pejabat pengelola, dewan pengawas, dan pegawai BLU/BLUD dapat diberikan berdasarkan tanggung jawab dan tuntutan profesionalisme yang diperlukan sebagaimana diatur dalam Pasal 36 ayat (1) dan (2) Peraturan Pemerintah Nomor 23 Tahun 2005 tentang Pengelolaan Keuangan BLU.

\section{Pembinaan dan Pengawasan}

Ketentuan mengenai pembinaan dan pengawasan diatur oleh Peraturan Pemerintah Nomor 23 Tahun 2005 tentang Pengelolaaan Keuangan Badan Layanan Umum, khususnya Pasal 34, dimana dikatakan bahwa pembinaan teknis BLU/BLUD dilakukan oleh menteri/pimpinan lembaga/kepala SKPD terkait. Ini berarti bahwa pembinaan teknis dipegang oleh instansi yang mengusulkan instansi Pemerintah Pusat atau Pemerintah Daerah menjadi BLU ataui BLUD, mengingat instansi tersebut dianggap mengetahui alasan teknis mengapa instasi dalam lingkungan pemerintah atau Pemerintah Daerah tersebut dijadikan BLU atau BLUD.

Dalam kaitan pembinaan teknis masalah kualitas dan tarif sangat penting karena selain melakukan pembinaan teknis ke dalam BLU/ BLUD itu sendiri, masyarakat pengguna layanan Umum ini pun setiap daerah berbeda, baik dari jenis layanan, kemampuan layanan Umum yang mereka harapkan.

Pembinaan keuangan BLU dilakukan oleh Menteri Keuangan, sedangkan PPKD sesuai dengan kewenangannya melakukan pembinaan di bidang keuangan dari BLUD. Selanjutnya dalam, pelaksanaan pembinaan tersebut dapat dibentuk dewan pengawas, yang pembentukannya sebagaimana tersebut di atas memerlukan pertimbangan persyaratan jika BLU/BLUD yang memiliki realisasi nilai omzet tahunan menurut laporan realisasi anggaran atau nilai aset menunjukkan neraca yang memenuhi syarat minimum Yang ditetapkan oleh Menteri Keuangan untuk BLU dan gubernur/bupati/walikota untuk BLUD.

Pada BLU/BLUD diperlukan pemeriksaan internal yang dilaksanakan oleh Satuan Pemeriksa Internal (SPI) yang bertanggung jawab langsung kepada pimpinan BLU/BLUD, selain 
Adminitrative Law \& Governance Journal Vol. 1 Edisi Khusus 12018 ISSN 2621 - 2781 Online

pemeriksaan eksternal yang dilakukan oleh Badan Pengawasan Keuangan dan Pembangunan (BPKP), yang laporan hasil pemeriksaannya hendaknya dinilai ulang oleh Badan Pemeriksa Keuangan (BPK), agar terdapat objektivitas. Adapun maksud hasil laporan BPKP atas BLU/BLUD oleh BPK ialah pertama, agar terjadi check and recheck pelaksanaan pemeriksaan yang dilakukan oleh pemeriksa sebelumnya yang dalam hal ini adalah BPKP. Kedua, agar pemeriksaan tersebut dapat dilakukan dengan lebih akurat, karena hasil atau laporan pemeriksaan (BPKP) tersebut akan dinilai ulang oleh insitusi pemeriksa yang lain yang lebih tinggi (BPK) sehingga pemeriksa dalam melakukan pemeriksaan akan sangat teliti karena ia (BPKP) mengetahui bahwa hasil pemeriksaannya akan diperiksa ulang oleh pemeriksa yang lebih tinggi (BPK). Ketiga, dengan demikian, tidak akan terjadi duplikasi atau tumpang tindih (over lapping) pemeriksaan yang tidak hanya mubazir, tetapi juga lebih efisien, efektif, clan ekonomis sehingga objek pemeriksaan tidak bertubi-tubi melayani pemeriksa, dan BLU/BLUD sebagai objek pemeriksaan (obrik) dapat lebih terfokus dalam melaksanakan tugasnya dengan penuh dan bertanggung jawab.

BLU/BLUD sebagai solusi debirokratisasi masih perlu dibuktikan, mengingat selain perubahan sistem dan mekanisme yang dilakukan, khususnya di bidang keuangan dengan menerapkan Pola Pengelolaan Keuangan Badan Layanan Umum (PPK-BLU), masih perlu sistem tersebut dievaluasi secara lebih rinci dan berkala, agar BLU/BLUD dapat berfungsi secara optimal dan dapat menumbuhkembangkan instansi pemerintah yang memberikan pelayanan kepada masyarakat dapat tercapai dengan layanan prima, berkualitas, transparan dan akuntabel.

\section{Simpulan}

Berdasarkan penelitian yang telah dilakukan, maka dapat disimpulkan bahwa Badan Layanan Umum (BLU) sebagai penyelenggara pelayanan publik berperan penting dalam memberikan layanan kepada masyarakat berupa penyediaan barang dan/atau jasa. Secara yuridis BLU bukan merupakan badan hukum, namun BLU beroperasi sebagai unit kerja kementerian negara/lembaga/pemerintah daerah untuk tujuan pemberian layanan umum yang pengelolaannya berdasarkan kewenangan yang didelegasikan oleh instansi induk yang bersangkutan. Oleh karena itu maka pengelolaan keuangannya tidak terpisah dari kementerian negara/lembaga/pemerintah daerah sebagai instansi induknya.

Adapun sarannya adalah bawa Perlu segera diwujudkan undang-undang tentang Badan Layanan Umum (BLU) sehingga BLU sebagai institusi penyelenggara layanan publik dapat lebih meningkatkan kinerjanya dalam mewujudkan kesejahteraan rakyat, didukung landasan yuridis yang lebih kuat. 


\section{Daftar Pustaka}

Atmadja, Arifin P. Soeria, 2013, Keuangan Publik dalam Perspektif Hukum, Edisi Ketiga, Jakarta, Rajawali Press

Fahmal, HA Muin, 2006, Peran Asas-asas Umum Pemerintahan yang Layak dalam Mewujudkan Pemerintahan yang Bersih, Yogyakarta, UII Press

Fuadi, Munir, 2009, Teori Negara Hukum Modern (Rechstaat), Bandung, Refika Aditama.

HR, Ridwan, 2013, Hukum Administrasi Negara, Jakarta, PT Raja Grafindo Persada.

Khairandy, Ridwan dan Camelia Malik, 2007, Good Corporate Governance, Perkembangan Pemikiran dan Implementasinya di Indonesia dalam Perspektif Hukum, Yogyakarta, Total Media.

Lukman, Mediya, 2013, Badan Layanan Umum, dari Birokrasi Menuju Korporasi, Jakarta, PT Bumi Aksara

Marbun, SF dan Moh. Mahfud MD, 1987, Pokok-pokok Hukum Administrasi Negara, Yogyakarta, Liberty

Mardiasmo, 2002, Otonomi dan Manajemen Keuangan Daerah, Yogyakarta, Penerbit Andi

Ratminto dan Atik Septi Winarsih, 2013, Manajemen Pelayanan, Pengembangan Model Konseptual, Penerpan Citizen's Charter, dan Standar Pelayanan Minimal, Yogyakarta, Pustaka Pelajar

Saidi, Muhammad Djafar dan Rohana Hoseng, 2010, Hukum Penerimaan Negara Bukan Pajak, Jakarta, PT Raja Grafindo Perkasa

Saidi, Muhammad Djafar, 2011, Hukum Keuangan Negara, Edisi Revisi, Jakarta, PT Raja Grafindo Persada.

Saragih, Juli Panglima, 2003, Desentralisasi Fiskal dan Keuangan Daerah dalam Otonomi, Jakarta, Ghalia Indonesia

Soemitro, Ronny Hanitijo, 1994, Metodologi Penelitian Hukum dan Yurimetri, Jakarta: Ghalia lndonesia.

Sutedi, Adrian, 2010, Hukum Keuangan Negara, Jakarta, Sinar Grafika

Syadullah, Makmun dan Nizar, Muhammad Afdi, 2013, Kebijakan Fiskal, Jakarta, ORTAX

Tjandra, W Riawan, 2008, Hukum Administrasi Negara, Yogyakarta, Penerbit Universtas Atmajaya

PERATURAN PERUNDANG-UNDANGAN

Undang-undang Dasar Negara Republik Indonesia Tahun 1945 Pajak

Undang-undang Republik Indonesia Nomor 20 Tahun 1997 tentang Penerimaan Negara Bukan

Undang-undang Republik Indonesia Nomor 17 Tahun 2003 tentang Keuangan Negara

Undang-undang Republik Indonesia Nomor 19 Tahun 2003 tentang BUMN

Undang-undang Republik Indonesia Nomor 1 Tahun 2004 tentang Perbendaharaan Negara

Undang-undang Republik Indonesia Nomor 32 Tahun 2004 tentang Pemerintahan Daerah

Undang-undang Republik Indonesia Nomor 33 Tahun 2004 tentang Perimbangan Keuangan antara Pemerintah Pusat dan Pemerintahan Daerah

Undang-undang Republik Indonesia Nomor 25 Tahun 2009 tentang Pelayanan Publik, Daerah

Undang-undang Republik Indonesia Nomor 28 tahun 2009 tentang Pajak Daerah dan Retribusi

Peraturan Pemerintah Republik Indonesia Nomor 23 Tahun 2005 tentang Pengelolaan Keuangan Badan Layanan Umum 